WORKING PAPERS No. 56

\title{
COMMERCIAL BANKS IN THE SECURITIES BUSINESS: A REVIEW
}

\author{
by \\ João A. C. Santos
}

June 1998

BANK FOR INTERNATIONAL SETTLEMENTS

Monetary and Economic Department

BASLE 
BIS Working Papers are written by members of the Monetary and Economic Department of the Bank for International Settlements, and from time to time by other economists, and are published by the Bank. The papers are on subjects of topical interest and are technical in character. The views expressed in them are those of their authors and not necessarily the views of the BIS.

(C) Bank for International Settlements 1998

CH-4002 Basle, Switzerland

Also available on the BIS World Wide Web site (http://www.bis.org).

All rights reserved. Brief excerpts may be reproduced or translated provided the source is stated.

ISSN 1020-0959 


\title{
COMMERCIAL BANKS IN THE SECURITIES BUSINESS: A REVIEW*
}

\author{
by
}

João A. C. Santos

June 1998

\begin{abstract}
This paper analyses the potential effects of commercial banks' expansion into the securities business in the context of the contemporary theory of financial intermediation. The analysis focuses on the gains claimed to emerge with that expansion, particularly the gains due to information advantages and economies of scope, and on the costs also claimed to arise with it, namely, those due to conflicts of interest and safety and soundness considerations. The paper ends with a discussion on how these effects depend on the location of the securities unit within the banking conglomerate.
\end{abstract}

* The author wishes to thank Claudio Borio, Kostas Tsatsaronis and two anonymous referees for their comments and suggestions. Part of this research was developed while the author was at the Federal Reserve Bank of Cleveland. The views stated herein are those of the author and are not necessarily the views of the Federal Reserve Bank of Cleveland or of the Board of Governors of the Federal Reserve System or of the Bank for International Settlements. 



\section{Contents}

Introduction

1. Potential benefits of universal banking ……............................................................. 3

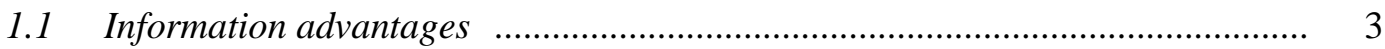

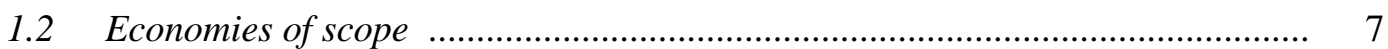

2. Potential costs of universal banking ……............................................................ 9

$2.1 \quad$ Conflicts of interest …..................................................................................... 9

$2.2 \quad$ Bank safety and soundness …….............................................................. 12

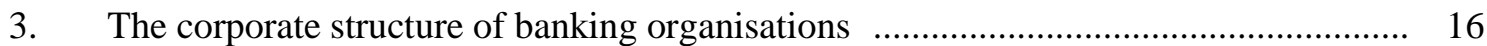

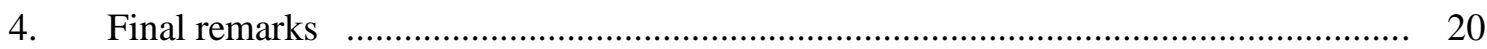

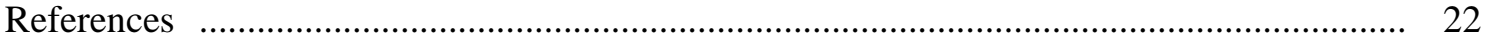





\section{Introduction}

The debate on the relationship between depository institutions' scope and their efficiency and stability has attracted additional interest in the United States in recent years because of successive attempts to repeal the Glass-Steagall Act and so expand the securities powers of commercial banking conglomerates. This issue has now moved to the forefront of public awareness because of differences in proposals made by the two main regulatory agencies - the Federal Reserve System and the Office of the Comptroller - regarding the location of the securities unit within the banking conglomerate.

This paper reviews the two strands of the literature most prominent in that debate. The first strand identifies the potential advantages and disadvantages of combining the traditional commercial banking activities with securities activities. The second strand studies how dependent these effects are on the location of the securities unit within the banking conglomerate. ${ }^{1}$

If we lived in an Arrow-Debreu world, there would be no need for financial intermediaries, except perhaps to reduce transaction costs. Information frictions, however, create a role for financial intermediaries. Under these circumstances, it is well established that financial intermediaries such as depository institutions can improve the allocation of resources by offering liquidity services (transforming illiquid assets into liquid liabilities, as in Bryant (1980) and Diamond and Dybvig (1983)) and by providing monitoring services (acting as delegated monitors of investors, as in Diamond (1984)). ${ }^{2}$

However, more general questions about the optimal design of the financial system and the optimal scope of financial intermediaries remain unanswered. Research on these issues is still in its infancy and it has been hampered by the complexity of the problems involved. This explains why only some partial aspects of these questions have been addressed. For example, Allen and Gale (1997) compare the intertemporal and cross-sectional risk-sharing opportunities offered to investors by a banking-based system with those offered by a market-based system; Boot and Thakor (1996) analyse the relationship between financial innovation and banking scope; and Gorton and Haubrich (1987) and

1 The issues at stake in combining commercial banking with insurance and with commerce are not addressed here. The former are surveyed in OECD (1992), Kane (1996) and Eisenbeis (1996), while the latter are reviewed in Saunders (1994) and Santos (1998a).

2 Gorton and Pennacchi (1990) also derive a theory of financial intermediation based on the provision of liquidity services. In their model, financial intermediaries provide liquidity services by designing securities that protect uninformed investors from the costs they would incur when trading with investors that possess superior information. In the Diamond and Dybvig model, financial intermediaries provide liquidity services by designing securities that insure investors against a random shock to their preferences for the timing of consumption. See Bhattacharya and Thakor (1993) or Freixas and Rochet (1997) for an extensive review of the banking literature. 
Boot and Thakor (1997) propose theories to explain the simultaneous existence of banks and financial markets.

With respect to the relationship between depository institutions' powers and their efficiency and stability, the debate usually considers (1) the reasons for the existence of these intermediaries (the provision of liquidity and the performance of monitoring services), (2) the problems generally associated with these institutions (being subject to runs and to failure), and (3) the devices most commonly adopted to address these problems (governmental deposit insurance and discount window facilities).

Research shows that banks' provision of liquidity services leaves them subject to runs. The reason is that the liquidation value of a bank's portfolio of assets is less than the value of liquid deposits, a necessary condition for the bank to provide liquidity. Under these circumstances, a run can occur even without the release of adverse information about the bank's assets. If depositors panic, they may try to withdraw their funds out of fear that other depositors will do so first, thus forcing an otherwise sound bank into bankruptcy (Diamond and Dybvig (1983)). ${ }^{3}$

Banks may also fail for other reasons. They may not be able to completely diversify the risk associated with their assets because markets are incomplete or because their monitoring technologies are not perfect. As a result, a run may occur if depositors realize that the value of a bank's assets is low, thus making withdrawing a dominant strategy. In this case, a run may be triggered, for example, by the release of information on the quality of the bank's assets (Jacklin and Bhattacharya (1988)).

A bank run is costly because it forces the premature liquidation of assets, thus disrupting the production process. Furthermore, it may trigger contagion runs, which may culminate in a system failure with strong negative effects on the economy. ${ }^{4}$ The risk of a system failure and the recognition of banks' importance for the smooth functioning of an economy have in turn motivated the development of mechanisms, such as governmental deposit insurance and discount window facilities, to insulate banks from runs. ${ }^{5}$

These mechanisms introduce problems of their own. Governmental deposit insurance, for example, reduces depositors' incentives to monitor banks and gives banks risk-shifting incentives when it charges them premiums that do not reflect their risk. ${ }^{6}$ These distortions are often used to

3 A bank could be funded instead by a debt contract that is traded in secondary markets. However, Jacklin (1987) and Chari and Jagannathan (1988) identify conditions under which a deposit contract dominates that contract.

4 Gorton (1988) shows how a bank run may lead to a panic, that is, a simultaneous run on many banks.

5 See Bhattacharya and Thakor (1993) for a discussion on the effectiveness of deposit insurance compared with other insulating mechanisms, such as the suspension of convertibility.

6 The risk-shifting incentives are further increased when forbearance practices are embraced and when "too-big-to-fail" policies are adopted. On the other hand, these incentives are restrained by the costs of going bankrupt, namely, the loss of the bank's charter and the loss of reputation. 
justify the introduction of a wide range of regulations. Some, such as prudential regulations, aim at restraining banks' incentives to undertake risk. Others, such as restrictions on the permissible activities, are designed to limit banks' opportunities to implement risk-shifting policies.

This paper focuses on banks' permissible activities. In particular, it reviews both the theoretical and the empirical evidence on what are usually recognised as the most important arguments in the debate over the securities powers of commercial banks. ${ }^{7}$ The paper proceeds as follows: Sections 1 and 2 discuss the potential advantages and disadvantages from combining traditional commercial banking with securities activities, respectively. Section 3 discusses how these effects depend on the location of the securities unit in the banking conglomerate. Section 4 concludes the paper.

\section{Potential benefits of universal banking}

An analysis of the effects associated with commercial banks' expansion into the securities business, particularly the underwriting of corporate securities, should consider why commercial banks exist in the first place. Traditional literature focused on banks' provision of payment and portfolio services. In contrast, contemporary theory of financial intermediation emphasises banks' role as providers of liquidity and as delegated monitors in environments characterised by asymmetries of information among participating agents. Within the framework adopted in the modern literature, it is usually conjectured that commercial banks' main gains from expansion into the securities business result from their information advantages and from economies of scope.

\subsection{Information advantages}

Firms generally have information about their creditworthiness and about relevant features of their investment projects that is not readily available to outsiders. ${ }^{8}$ Some firms can reduce the information gap by contracting with an independent agent (a rating agency) that conveys the relevant information to outsiders and at the same time certifies its quality. ${ }^{9}$ Rating agencies have an incentive to provide accurate information in order to maintain their reputation, while firms are willing to incur

7 For the purposes of this paper, a universal bank is an institution that is allowed to perform a wide range of activities inhouse, such as accepting deposits, making loans, acting as a broker and dealer in the securities market, and underwriting securities. Two other powers usually attributed to universal banks - taking equity positions in nonfinancial firms and conducting insurance business - are not discussed here.

8 Several researchers have used information asymmetries to explain the firm's capital structure and the design of securities. See Harris and Raviv (1991) and Allen and Winton (1995), respectively, for reviews of the literature on these topics.

9 Holthausen and Leftwich (1986), Stickel (1986) and Hand, Holthausen and Leftwich (1992) find empirical evidence that credit rating agencies provide valuable information to outside investors by studying the effects of these agencies' announcements on the firms' stock prices and on their bond prices. 
the costs of that process because it gives them access to capital markets and so saves them the costs of contracting with a bank. Other firms, however, are not able to reduce the information gap by making use of rating agencies. The production of information about these firms may be too costly or it may require a continuous and extensive relationship with them. Under these circumstances, important savings can be achieved by delegating certain functions to financial intermediaries. The costs of financial intermediation are reduced by avoiding the duplication of functions such as gathering the relevant information about the borrower. ${ }^{10}$

In establishing a relationship with a firm, the bank incurs the costs of gathering information about the firm and its investment opportunity before making the funding decision. Once this decision is made, a new stage of the bank-firm relationship begins; the bank starts monitoring the firm, making sure that it observes the conditions of the funding contract and, at the same time, gathering further information about the firm. As a result, bank financing tends to be more expensive than public financing, thus explaining why firms tend to avoid the former type of funding. Moreover, some firms may also avoid bank funding to avert the additional scrutiny that usually comes with it. Because of this, firms with a higher reputation (usually larger firms) tend to raise funding directly in capital markets, while smaller and younger firms tend to rely on banks. ${ }^{11}$

Within that set-up, it is usually conjectured that universal banks have some advantages over specialised ones. By offering a broader set of financial products than a specialised bank, a universal bank can develop "wider" and longer-term relationships with firms. This enhancement of the bank-firm relationship may be a source of important gains to both parties. A "wider" bank-firm relationship may be a source of scope economies. It allows the bank to learn more about a firm by observing its behaviour with respect to more financial instruments and it gives the bank the opportunity to use the information it collects by monitoring a firm's checking account in various

10 Diamond (1984) and Ramakrishnan and Thakor (1984), among others, derive theories of financial intermediation based on information frictions. Consistent with intermediaries' role as producers of information, James (1987) finds that firms experience positive abnormal equity returns in response to announcements of bank credit agreements, and nonpositive effects in response to publicly placed debt. Mikkelson and Partch (1986) report similar results. Lummer and McConnell (1989) find that initial loan agreements have no effect on firms' equity returns but loan renewals result in abnormal equity returns. Slovin, Johnson and Glascock (1992) find that the announcement of both loan initiations and renewals has a positive effect on small firms' stock prices but no effect on those of large firms, a result consistent with the idea that bank monitoring is more valuable for smaller firms. Best and Zhang (1993) also report results that accord with the idea that bank monitoring is more valuable in the case of smaller firms.

11 Several authors have derived theories of bank-loan demand. Diamond (1991) shows that borrowers with moral hazard problems borrow from banks initially but, as they build their reputation, they start issuing debt directly in capital markets. Rajan (1992) shows that firms choose their borrowing sources and design their borrowing contracts so as to reduce the bargaining power that banks acquire because of what they learn about firms when they extend a loan. Chemmanur and Fulghieri (1994) show that banks' desire to acquire a reputation for making the "right" renegotiation versus liquidation decision makes them devote more resources to evaluating borrowers than bondholders. In equilibrium, borrowers with a lower probability of being in financial distress choose bonds over bank loans. Yosha (1995) shows that firms choose their borrowing source by taking into account that borrowing from capital markets forces them to disclose information that may be valuable to their competitors while borrowing from a bank creates the perception that they are hiding information, thus making competitors react in a way that jeopardises their profits. 
businesses rather than just in lending decisions. ${ }^{12}$ Furthermore, by offering a larger number of services, a universal bank has more instruments to consider in the design of financing contracts and more leverage over firms' managerial discretion, thus reducing agency costs. The empirical research on these scope economies is still very limited, but the results already unveiled are consistent with the existence of advantages in a "wider" bank-firm relationship. Petersen and Rajan (1994), for example, find that the larger the number of services a bank provides to a firm the greater the availability of funding.

The duration of the bank-firm relationship is also important. ${ }^{13}$ If both the bank and the firm expect to do business for a long time, then the bank is more willing to invest in gathering information about that firm and to spread the costs of such investment over a longer time horizon, reducing the up-front cost of capital to the firm.

The information available about a firm, its financial needs and its reputation change over its life cycle. As a result, a firm's ability to raise funding through the various financial instruments available and its ability to access the different providers of funding also changes over its life cycle. ${ }^{14}$ In the early stages of their existence, because they are unknown, firms tend to rely heavily on retained earnings and on funding provided by their founders. After a successful beginning, firms start raising most of their funding from banks, usually through loans. At this stage, they are highly dependent on banks' investment in information and on their monitoring services. As firms mature and develop a reputation they often divert to capital markets to raise funding, in many cases by issuing bonds initially and only some time later by issuing stock. ${ }^{15}$ In an evolution like that, unlike a specialised bank, a universal bank can fulfil a firm's funding needs throughout its existence. This fosters a longterm relationship that can be beneficial to both parties.

The bank is willing to enter into a long-term implicit contract only if it expects to do business with the firm for a prolonged period. To the extent that part of the information generated in the bank-firm relationship is private to the bank and not easily transferable by the firm to other parties, the firm will incur some costs if it decides to switch banks. These costs have a positive effect, in that they lend credibility to the implicit bank-firm contract. Because of this, the bank can make funding

12 Nakamura (1993) argues that banks gain important information by monitoring firms' checking accounts, particularly those of smaller firms. Shaffer (1984) and Udell (1986) argue that banks use checking account information to sort out customers of different quality types. Allen, Saunders and Udell (1991) find some empirical evidence consistent with that screening device.

13 Boot and Thakor (1994) show that, even without learning, a long-term bank-borrower relationship is still welfareimproving. The reason is that the long-term contract made possible by that relationship allows the bank efficiently to adjust the financing contract over time in order to reduce the use of (costly) collateral.

14 See Myers (1984) for an analysis of the "pecking order" explanation of the firm's capital structure and Hubbard (1997) for a review of the empirical research on the costs of external finance.

15 During this transition some firms raise funding from venture capitalists, in some cases by selling them a participation in their capital. This reduces firms' leverage and the presence of a reputable intermediary as one of the firm's shareholders provides a positive signal to outside investors. 
available on better conditions to firms in the early stages of their life cycle. But the switching costs also have a negative effect. They permit the bank to extract (ex post) "quasi-rents" associated with its information advantage even when ex ante rents had been competed away by the competition from the other banks. This gives firms an incentive to rely more on internal funds in order to avoid becoming too dependent on a bank in the first place. ${ }^{16}$

The critical issue regarding the switching costs arising in a bank-firm relationship, however, is how these costs compare when the relationship is in a universal banking system as opposed to a specialised banking system, and how the "quasi-rents" associated with them are extracted in each system. On the one hand, it is frequently argued that switching costs are larger in a universal banking system, thus giving banks an opportunity to extract more "quasi-rents". Two reasons are put forward to explain that difference. The first is the pre-emptive behaviour that a universal bank can adopt to deter other banks from competing for its client's businesses. Because of its better information, the bank can anticipate the firm's funding needs and so can prepare some of the necessary work in advance to gain an advantage over potential competitors.

The second is a new "lemons" problem that can arise when a firm leaves a universal bank. In a specialised banking system, when a firm switches from a commercial bank to an investment bank for the purpose of issuing in the market, no special meaning can be attached to this move except that the firm is interested in raising funds through a different channel. The investment bank knows that the firm's bank is not allowed to underwrite its securities. In a universal banking system, however, when the firm switches to an investment bank, this bank will wonder why the firm's bank does not provide the underwriting service. This doubt may create a "lemons" premium, thus raising the firm's switching costs.

On the other hand, it is also commonly argued that a universal banking system allows for a smoother extraction of the "quasi-rents". Because it creates the conditions for a long-term bank-firm relationship, a universal banking system enables the bank to extract such rents over a longer time horizon. As a result, financing costs in the early stages of the relationship may be lower than in a specialised banking system, where banks might need to extract the rents over a shorter time period (Calomiris (1995)).

Empirical research on bank-firm relationships finds evidence supporting the claim that these relationships are valuable. For example, Berger and Udell (1995) find that borrowers with longer banking relationships obtain better financing conditions in terms of both collateral and interest rates. Petersen and Rajan (1994) fail to find a positive association between the duration of the relationship and the interest rate charged, but they do find a positive impact on credit availability.

16 Greenbaum, Kanatas and Venezia (1989), Sharpe (1990) and Rajan (1992) study some of the implications of the information advantage gained by the bank in its relationship with a firm. 
In sum, there seem to be important information advantages associated with a universal banking system. That system allows for an enhancement of the bank-firm relationship because it permits additional points of contact between the parties and because it gives them the possibility of developing a long-term relationship. Empirical research on these issues is still in its early stages. However, the results already unveiled seem to confirm that the enhancement of a bank-firm relationship is a source of important benefits in terms of cost and availability of funding.

\subsection{Economies of scope}

Economies of scope are pivotal to the efficiency of financial conglomerates in general and universal banks in particular. They may arise both from the production of financial services and from their consumption. Regarding production, economies of scope are said to exist when the cost of one organisation producing a given mix of products is less than the cost of several specialised firms producing the same bundle of products. Baumol, Panzar and Willig (1981) suggest that economies of scope in production arise when there are inputs that are shared or used jointly.

In the previous section, we saw how universal banks may benefit from the economies of scope in information gathering. Universal banks may also benefit from the conventional technological economies of scope because, first, they can spread the fixed cost (in terms of physical and human capital) of managing a client relationship over a wider set of products (Steinherr and Huveneers (1990)). Second, they can use their branch networks and all their other existing delivery channels to distribute additional products at low marginal cost (Llewellyn (1996)). Third, they can face the shifts in demand for the products they offer (some of the products offered by financial institutions are, to a certain extent, close substitutes) more easily because they can respond by shifting resources within their organisations. Finally, to the extent that it is easier to gain reputation in some businesses than in others, and to the extent that there are spillovers in reputation, universal banks can use the reputation gained in offering one service to recommend their other services (Rajan (1996)). ${ }^{17}$

Economies of scope may also arise from the consumption of financial services. Consumers may save on searching and monitoring costs by purchasing a bundle of financial services from a single provider instead of acquiring them separately from different providers.

Thus, from a theoretical point of view, there appear to exist various sources of technological economies of scope associated with the combination of commercial banking with investment banking activities. The debate on the importance of these economies, however, has not

17 Several studies find evidence supporting the importance of financial intermediaries' reputation. Beatty and Ritter (1986) and Carter and Manaster (1990) find that the underpricing in initial public offers (IPOs) is associated negatively with the underwriter's reputation. Slovin, Sushka and Hudson (1990) report similar results for seasoned equity issues. Billet, Flannery and Garfinkel (1995) address the intermediaries' reputation issue but with respect to loan announcements. They find that the borrower's abnormal equity returns associated with bank loan announcements are positively correlated with the lender's credit rating. 
been settled. On one hand, the evidence found so far is mixed. Research on U.S. banks finds little support for economies of scope in the joint production of commercial and investment banking services. It is important to note, though, that at the time this research was developed commercial banking organisations were allowed to offer only limited investment banking services and these had to be housed in a subsidiary of a bank holding company (BHC) separated from the banks in that holding company by an extensive set of firewalls. ${ }^{18}$ Research on banks in Japan, Israel and some European countries, such as Belgium, France and Italy, finds stronger evidence of scope economies in the joint production of these services. ${ }^{19}$

On the other hand, the data and method that the empirical research on scope economies has generally used has been questioned. The traditional literature focused mainly on deposits and loans in samples of small banks. More recent studies have expanded that literature to include large banks, information issues and larger sets of financial products, but their conclusions continue to be questioned. ${ }^{20}$ Some researchers note the limitations and instability of the most popular method of accounting for scope economies - the estimation of cost economies through the translog cost function or its Box-Cox variants (Pulley and Humphrey (1993)). Others raise concerns about the quality of the data used, particularly the lack of micro data. Still others question the research on economies of scope because it does not take regime-change effects into account. Calomiris (1995), for instance, argues that the impact on banks' current profits and costs of combining different activities is not the correct way to estimate the scope economies that would result if the United States were to move to a universal banking system. The reason is that this procedure does not account for the fact that banks would change their policies with that change in the banking system. Finally, some researchers claim that the results reported in the literature are not representative of a universal banking system's potential economies of scope because they ignore the possible economies on the consumption side. Berger, Humphrey and Pulley (1996), however, find that economies of scope in the consumption of bank deposits and loans are insignificant in the United States. ${ }^{21}$

In conclusion, from a theoretical viewpoint there is a significant consensus that potentially important economies of scope are associated with universal banking. However, the empirical research thus far has not been able to generate the same consensus, partly because of its mixed results and partly because of problems with the approach it has adopted.

18 See Mote and Kaufman (1989) for the securities activities that BHCs were allowed to undertake over time, and GAO (1995) for a detailed list of the firewalls that BHCs were required to implement.

19 See Clark (1988), Mudur (1992) and Forestieri (1993) for a survey of the empirical research on economies of scope.

20 See Berger, Hunter and Timme (1993) for a discussion of some problems with the research on scope economies.

21 I am not aware of any empirical research on the economies of scope of the joint consumption of commercial and investment banking services. 


\section{Potential costs of universal banking}

The most frequent arguments for maintaining the separation between commercial banking and the securities business are that combining these activities would create serious conflicts of interest and would threaten the safety and soundness of the banking system. These arguments have a historical precedent: they were the main reasons invoked by the U.S. Congress for enacting the Glass-Steagall Act in 1933.

The investigation conducted by the Senate Banking and Currency Committee following the bank failures that occurred after the stock market crash of 1929 was highly influential in shaping public opinion at the time and in facilitating the enactment of the Glass-Steagall Act. Among other things, the Committee claimed that banks had been exploiting the conflicts of interest inherent in their securities dealings and that the securities activities were a major cause of the bank failures. Recent research on banks' securities activities prior to Glass-Steagall, however, finds no evidence for the claims of widespread abuse and failures due to these activities. Instead, this research concludes that some of the allegations made at the time regarding conflicts of interest were either unfounded or greatly exaggerated, and that banks engaged in securities activities had no higher risk of failing than banks with no links to the securities industry. ${ }^{22}$

After the enactment of Glass-Steagall, alleged conflicts of interest and threats to banks' stability continued to be evoked in defence of the separation between commercial banking and the securities industry. For example, a 1971 report by the President's Commission on Financial Structure and Regulation states that "this separation was prompted by the conflicts of interest that developed when the same organisation handled the two functions. The possibility of conflicts of interest would still exist if banks were again permitted to underwrite new issues of corporate securities. The Commission, therefore, strongly recommends the continued prohibition against bank underwriting of private securities issues." 23

\subsection{Conflicts of interest}

Edwards (1979, p. 282) defines conflicts of interest as follows: "A conflict of interest exists whenever one is serving two or more interests and can put one person in a better position at the expense of another." Bröker (1989, p. 228) states that "a conflict of interest arises for a bank ... dealing with a client if it has a choice between two solutions for a deal, one of which is preferable from its own interest point of view while the other represents a better deal for the client. A conflict of interest arises also for a bank ... if it carries out activities involving two different groups of customers and if it has to strike a balance between the respective interests of the two customer groups." In light

22 For a discussion of the events, including the Senate's Hearings, that culminated in the enactment of the Glass-Steagall Act see, for example, Carosso (1970), Kelly (1985a) and Benston (1990).

23 Report of the President's Commission on Financial Structure and Regulation, December 1971, p. 52. 
of these definitions, it becomes clear that even the existing specialised institutions face many situations where conflicts of interest may develop. Naturally, as financial institutions offer more products, and as the set of customers expands, so do the possibilities for conflicts to emerge.

With respect to commercial banks' expansion into the securities business, conflicts of interest are said to arise because of the bank's advisory role to depositors (the bank may promote the securities it underwrites, even when better investments are available in the market) and because of its role as a trust fund manager (the bank may "dump" into the trust accounts it manages the unsold part of the securities it underwrites). Conflicts of interest may also develop because of the bank's opportunity to impose tie-in deals on customers (the bank may use its lending relationship with a firm to pressure the firm to buy its underwriting services under the threat of increased credit costs or nonrenewal of credit lines) and because of the bank's ability to design deals aimed at transferring bankruptcy risk to outside investors (the bank may pressure a borrower that is in financial difficulties to issue securities that the bank will underwrite and sell to the public with the understanding that the proceeds of the issue are to be used to repay the loan). ${ }^{24}$ Finally, conflicts of interest may also arise because of "inside information" (the bank may use the confidential information that it learns when it underwrites a firm's securities in a way that the firm did not contemplate, such as to disclose that information, directly or indirectly, to the firm's competitors). ${ }^{25}$

The critical issue regarding any potential conflict of interest is not whether the conflict exists per se but rather whether the parties to the transactions have incentives - and opportunities - to exploit it. It is not clear that banks have a strong enough incentive to exploit the conflicts of interest listed above for several reasons, including the potential damage to their reputation, particularly to their certification role; the monitoring by bond rating agencies; and the supervision exercised by regulatory authorities. Furthermore, it is unclear that banks would have an opportunity to turn these conflicts to their advantage. In general, conflicts of interest can only be exploited when there is some monopoly power (as with tie-in deals) or asymmetry of information between the contracting parties (as in the conflict between the bank's promotional and advisory roles) or when one of the parties is "naïve" (as when securities are issued to transfer bankruptcy risk to outside investors).

Some of the conflicts of interest claimed to arise with commercial banks' expansion into the securities business, such as the dumping of securities into trust accounts, tie-in deals, or the "insider information" problems, are already present, to a certain extent, in existing specialised institutions. The ability to exploit these conflicts, however, has been restricted by legal constraints (such as the Securities Act of 1933, which defines, among other things, the disclosure requirements to

24 See Rajan (1994), Puri (1995) and Kanatas and Qi (1995) for a formal analysis of the conflicts associated with the bank's certification role when it underwrites its clients' securities.

25 See Edwards (1979), Saunders (1985a), Kelly (1985b) and Benston (1990) for a detailed discussion of these and other conflicts of interest. 
be met in the issuance and distribution of securities to the public), ${ }^{26}$ private self-regulatory standards adopted by the participating institutions (such as the disclosure rules and firewalls that commercial and investment banks have adopted to deal with the new conflicts of interest arising from their involvement in derivatives contracting, namely those resulting from their simultaneous participation as advisors to the client on what product to use and as the counterparties who provide that product), ${ }^{27}$ market forces (such as the competition from other financial institutions) and "nonmarket" monitors (such as rating agencies). Finally, economic theory suggests that if agents are moderately rational, when they enter into a contracting relationship they will consider the other party's incentives and, as a result, they will not generally be fooled. For example, if firms perceive that they may be forced into future tie-in deals they can protect themselves in advance by maintaining relationships with more than one bank. If investors perceive that a bank has been exploiting a certain conflict of interest they can take that into account by applying a "lemons" discount to the bank's products affected by such conflict.

Empirical research on the conflicts of interest associated with commercial banks' securities activities has not uncovered strong evidence supporting the claim that banks do exploit these conflicts. For the period before Glass-Steagall, Kroszner and Rajan (1994), comparing the ex post default performance of ex ante similar securities underwritten by commercial banks (either through trust departments or through affiliates) with those underwritten by investment banks, find no evidence that commercial banks systematically fooled the public by offering low-quality securities. Instead, their findings indicate that commercial banks underwrote higher-quality securities, which performed better than comparable securities brought to the market by investment banks. These findings confirmed the results of two other independent studies, by Ang and Richardson (1994) and Puri (1994). ${ }^{28}$

Some have questioned these studies because of their use of the default rate as the performance variable. The reason is that it is a one-time-event variable, which does not capture the continuous variation in value over the bond's lifetime (Calomiris (1992)). However, studies that have looked at other performance variables have found results consistent with research that used the default rate. For example, Ang and Richardson (1994) find, for the period prior to Glass-Steagall, that bonds issued by commercial banks' affiliates had lower ex ante yields and higher ex post prices than those issued by investment banks. For the same period, Puri (1996) finds that securities underwritten by commercial banks had higher prices (lower yields to maturity) than comparable securities underwritten

26 See Kelly (1985b) for additional examples of regulations dealing with the conflicts of interest associated with the provision of securities services.

27 The author wishes to thank one of the referees for pointing out this conflict of interest and the procedure that banks have adopted to address it.

28 Moore (1934) and Edwards (1942) also found evidence compatible with these results. 
by investment banks, which suggests that investors perceived commercial banks' certification role, net of conflicts of interest, to be more valuable than that performed by investment banks.

There has also been some research on conflicts of interest associated with commercial banks' securities activities in modern banking systems. The Gessler Commission carried out an extensive study of that issue in relation to the German banking system in the late 1970s. Krümmel (1980, p. 46) summarises its findings as follows: "On the whole, consideration of potential conflicts of interest in universal banking did not lead the Commission to recommend the separation of the banking functions but rather to conclude that restraints of competition caused by such conflicts of interest are small and can be remedied or abolished by provisions within the existing system". More recently, Gande, Puri, Saunders and Walter (1997) have studied conflicts of interest in the present US banking system by comparing the bonds underwritten by BHCs' Section 20 subsidiaries with those underwritten by investment banks. Once again, their results suggest that the certification role of commercial banking organisations, net of conflicts of interest, is more valuable than that of investment banks.

In conclusion, some of the conflicts of interest that could develop if commercial banks expand into the securities business already exist in the specialised institutions. Others could result from enlargement of the range of banks' activities and customers. Despite that growth, banks will exploit conflicts of interest only if they have the incentives and opportunities to do so. The incentives are constrained by the importance that banks attribute to their reputations. The opportunities are limited by investors' expected behaviour, by competition in the financial markets and by existing regulations, such as those on disclosure.

\subsection{Bank safety and soundness}

The negative externalities that may result from a bank failure continue to be used as a major justification for making bank soundness the subject of regulation. ${ }^{29}$ It is frequently argued that the failure of a bank, particularly of a big bank, may spread domino-fashion, forcing other banks (solvent and insolvent) into bankruptcy and creating a system failure. ${ }^{30}$

A bank may fail because of liquidity problems (a run on its deposits may lead to the failure of a healthy bank because it forces the bank to liquidate its assets in a very short period of time) or because of other problems, such as a systemic shock (a deep recession, for example, may lead to a situation where the bank's losses exceed its capital) or fraud. In most countries, the desire to protect banks from runs on their deposits and to reduce the risk of a system failure led to the development of

\footnotetext{
29 See Dewatripont and Tirole (1994) for an extensive analysis of prudential regulation.

30 See Calomiris and Gorton (1991) for a review of the literature on bank panics.
} 
governmental deposit insurance systems and discount window facilities. ${ }^{31}$ However, these mechanisms create problems of their own. Most notably, they reduce depositors' incentives to monitor banks and they give banks incentives to take excessive risk. ${ }^{32}$ These problems, in turn, have been used to justify banking supervision and regulation. They have also been used as an argument for implementing a system of narrow banks. In that system banking organisations, such as holding companies, would own a bank, which would invest insured deposits in risk-free assets (short-term government securities), and other affiliates, which would be financed by securities not federally insured and would conduct the other businesses, such as lending and securities activities (Kareken (1986), Litan (1987), Bryan (1988), Pierce (1991) and Gorton and Pennacchi (1992)). These affiliates would be completely separated from the bank by an extensive set of firewalls. ${ }^{33}$

With regard to banking regulation, some of it, such as the capital requirements, aim at limiting banks' incentives to undertake too much risk. Other regulations, such as the restrictions on banks' permitted activities, aim at limiting banks' opportunities to undertake too much risk. The prohibition on U.S. commercial banks undertaking investment banking activities is often presented as an example of the latter group of regulations.

Investment banking activities can be divided into agency-type activities and principaltype activities. In the former, the investment bank acts as an agent; that is, it conducts two-way transactions on behalf of customers. These include acting as a securities broker, as a "placement" agent in private underwritings and on a best-efforts basis in public underwritings. In the principal-type activities, the bank acts as a principal; that is, it conducts transactions for its own account. These include firm-commitment underwritings of public issues and securities dealing. Agency-type activities are usually perceived to be less risky than principal-type activities because they are mainly fee-based

31 See Diamond and Dybvig (1983) for an analysis of the importance of governmental deposit insurance in eliminating bank runs.

32 Calomiris and Khan (1991) focus on depositors' monitoring role to explain the importance of banks being financed with demandable debt. Depositors can monitor the bank because they can withdraw their funds when they observe unacceptable policies. In this case, and in contrast to Diamond and Dybvig (1983), a bank run is beneficial and deposit insurance is unwarranted. However, if depositors' monitoring is noisy deposit insurance may have an important role. Kareken and Wallace (1978), Merton $(1977,1978)$ and Dothan and Williams (1980), among others, analyse the riskshifting incentives introduced by deposit insurance. Schwartz (1992) discusses the problems associated with the discount window.

33 Proponents of a system of narrow banks argue that it creates "fail-safe" banks, where deposit insurance plays a minimal role and is available only to cover losses resulting from extraordinary events, such as fraud. Although the proposal was appealing when first introduced, closer consideration has revealed important problems, some of which remain unsolved. For example, when confronted with the observation that there are not enough risk-free securities to provide the counterpart of transaction deposits, the narrow banking proponents suggest broadening the set of banks' permissible investments to include long-term government bonds and high-grade commercial paper. This extension, however, reintroduces interest rate risk and credit risk into the banks, thus enlarging the role of deposit insurance. In addition, as is widely recognised, one of banks' key functions is the creation of liquidity. Under a narrow banking system, banks would not be allowed to perform this function. It is possible that the new firms that would move in to fill the vacuum left by banks would inherit the problem of runs, thus requiring regulators to step in and eventually extend some form of insurance coverage to these firms' creditors (Diamond and Dybvig (1986) and Wallace (1996)). 
while in the principal-type activities the investment bank attempts to profit by acquiring securities in the expectation of reselling them at a higher price. This makes the profitability of the principal-type activities very dependent on the bank's assessment of the value of the securities and on that of the market. ${ }^{34}$

For example, in the case of securities underwriting, the risk occurs mainly in the case of firm-commitment underwriting of public issues. The securities firm may not be able to resell the securities it underwrote at a price high enough to cover the costs of the operation and the price guaranteed to the issuer. Research finds that IPOs of common stock are usually underpriced. Smith (1986) reviews that literature and concludes that on average underpricing exceeds 15 per cent. The evidence, however, is less clear in the case of seasoned offerings. Loderer, Sheehan and Kadlec (1991) find little evidence that underwriters systematically set offer prices below the market price on the major exchanges (NYSE and Amex), but they find evidence of underpricing for NASDAQ issues.

As it happens in the underwriting business, the risks incurred by the principal in the trading business vary with the activities performed. For example, when a securities firm buys a block of securities to facilitate a customer trade, it incurs the risk of having to resell that block later at a lower price. Holthausen, Leftwich and Mayers (1987) find that transactions of large blocks of common stocks have a price effect that is predominantly temporary for seller-initiated transactions and permanent for buyer-initiated transactions. These studies reveal important information about the performance of the underwriting and trading businesses on a stand-alone basis. ${ }^{35}$ However, the issue relevant to the debate on commercial banks' expansion into the investment banking business is the potential risk effects for banks and BHCs from performing those securities activities. Some research has provided important information for that debate by studying commercial banks' securities activities prior to Glass-Steagall. White (1986) studies the securities activities of national banks before 1933 . He finds that both the mean and the coefficient of variation of four measures of profitability were greater for the securities affiliate than for the bank, and that the coefficients of correlation for these measures between the bank and the securities affiliate were insignificant in all cases. He also finds that the existence of a securities affiliate or a bond department had either a decreasing impact or no impact at all on the probability of failure of the banks included in his sample.

Other research has attempted to evaluate the securities activities impact on banking organisations' risk using data on the existing banks and securities firms. Some studies focus on the securities activities that banking organisations are already allowed to perform. For example, Kwast

34 The development in recent years of the derivatives market has given investment banks an opportunity to hedge the risk in certain activities that they perform as principal agents. See Saunders and Walter (1994, Chapter 5) for a detailed discussion of this issue and an analysis of the risks associated with various investment banking activities.

35 Saunders (1985b) finds that the volatility of the yield on Moody's Aaa corporate bonds was lower than that observed for the yields on state and local general obligation bonds over the period 1978-83, a period when banks were allowed to underwrite municipal general obligation bonds but not corporate bonds. 
(1989) finds, on the basis of firm-level data on banks' trading accounts for the period 1976-85, that the correlation between the return on securities activities and the return on banking activities is time and bank-size dependent. He also finds the maximum percentage of assets devoted to securities activities that yields diversification gains to be less than 5.0 percent. Other studies focus on the potential risk impact of new securities activities. For example, Wall and Eisenbeis (1984), using accounting data at the industry level, find that there was a negative correlation between bank earnings and securities broker/dealer earnings over the period 1970-80. Litan (1987, 1985) finds, on the basis of Internal Revenue Service profit data, that the correlation between bank profits and securities broker/dealer profits is time-dependent. Litan also estimates that the share of the securities activities in the portfolios on the efficient risk/return frontier is less than 4.0 percent. Brewer, Fortier and Pavel (1989) find, on the basis of daily stock market returns for a sample of banks and nonbanking firms that were actively traded in 1980, 1982 and 1986, a positive correlation between the average daily returns of banking and securities brokers/dealers. They also find that a hypothetical merger of a "representative banking firm" with a "representative securities firm" would increase the variance of the banking firm's average daily returns.

Some researchers have examined the risk effects of banking firms' expansion into the securities business by studying hypothetical mergers between BHCs and securities firms. Boyd, Graham and Hewitt (1993) extend the earlier work by Boyd and Graham (1988). They use accounting and market data over the period 1971-87. The authors find that mergers between BHCs and securities firms generally increase BHCs' risk of failure (measured by an indicator of the probability of bankruptcy). Santomero and Chung (1992) also use the hypothetical merger approach. They use market data over the period 1985-89 and, like the previous studies, they use the probability of bankruptcy as the measure of risk. Their approach, however, differs from those studies in that they use option-pricing theory to estimate the implied volatility of the rate of return on assets and the market value of assets. ${ }^{36}$ Santomero and Chung find that mergers between BHCs and regional securities firms usually lead to a reduction in the BHCs' risk. However, mergers between BHCs and large securities firms generally lead to an increase in the new organisations' risk of failure.

The empirical literature on the potential risk to banks from undertaking securities activities has been questioned on several grounds. Some studies have been questioned for using the variability of profits as a measure of risk instead of the more appropriate probability of bankruptcy. Others have been questioned for using industry-level data, which introduces an aggregation bias. ${ }^{37}$ The studies of hypothetical mergers between banks and securities firms have also been questioned for not taking into account the effects of policy changes that usually follow a merger. The outcome of a merger between two firms is not the same as the combination of their balance sheets. Firms change

36 Boyd et al. (1993), for example, estimate the market value of assets as the sum of the market value of equity plus the accounting value of debt plus preferred stock.

37 See Boyd, Hanweck and Pithyachariyakul (1980) for a discussion of the aggregation bias in these studies. 
their policies after the merger in order to take advantage of, for example, the scope economies associated with the new mix of activities that they undertake.

In sum, the research on the potential risk to banks from conducting securities activities finds mixed results. These results, however, appear to disprove the idea that the securities business is highly risky for banks. On balance they show that the securities business gives banks some potential diversification gains, but these seem to be somewhat limited.

\section{The corporate structure of banking organisations}

The potential benefits and costs of allowing commercial banks to undertake securities activities largely depend on the latitude they have to integrate these activities with their current mix of businesses. This latitude in turn depends on the freedom banks have in placing the securities activities within their organisational structure.

In a deregulated system, there are several possible corporate structures that banks can adopt to combine commercial banking with securities activities. The most frequently chosen are a universal bank, a bank with a securities subsidiary, and a holding company with a banking subsidiary and a securities subsidiary. ${ }^{38}$ In the universal banking model, banks can completely integrate the activities they choose to undertake because they can conduct all of them within a single corporate entity. In the bank-parent and holding-company models, commercial banking activities and securities activities are conducted in legally distinct entities with separate management teams and separate capital. As a result, integration can only be partially achieved. It is constrained further when there are restrictions on the financial and operational relationships between the bank and the securities subsidiary.

In the debate over the most recent attempt to repeal Glass-Steagall, the Federal Reserve Bank, the Office of the Comptroller and the FDIC have been in agreement on the expansion of commercial banking organisations' securities powers and on the requirement that these activities be conducted in a separately capitalised unit of the banking conglomerate. They have, however, proposed different ways to implement the separation. The Federal Reserve Bank has advocated the holdingcompany model, and the Comptroller and the FDIC have proposed letting banks choose between that model and the bank-parent model. ${ }^{39}$

38 Herring and Santomero (1990) and Koguchi (1993) present some variants of these structures.

39 Prior to Glass-Steagall, particularly after the enactment of the McFadden Act in 1927, the emphasis of the regulation was on the activities that could be performed in-house versus those that would have to be undertaken in a separate unit (see Peach (1941) for a detailed analysis of the securities subsidiaries and affiliates created by banks prior to 1933). With the enactment of the Glass-Steagall Act in 1933 member banks were prohibited from affiliating with entities that were "principally engaged" in investment banking. Since 1987, the Fed has allowed BHCs to perform, through their so-called Section 20 subsidiaries, some "negligible" activities, such as underwriting commercial paper, but it limited the revenue 
Part of that debate's prominence results from the impact that banks' corporate structure will have in determining the regulatory agency that will oversee their securities activities. If these activities are performed by a subsidiary of a BHC, they will be supervised and regulated by the Federal Reserve Bank. If they are conducted by the bank itself or by a subsidiary of the bank, they will be overseen by the bank's regulator - the Federal Reserve in the case of a state member bank, the FDIC in the case of a state nonmember bank, and the Office of the Comptroller in the case of a national bank. However, the place where banks locate their securities services within their organisational structure has implications reaching far beyond the definition of their regulator. ${ }^{40}$

A variety of reasons is usually put forward to justify, for example, a regulation requiring securities activities to be undertaken outside the banking unit. ${ }^{41}$ These include the maintenance of the safety net coverage for the traditional banking activities; the elimination of the potential conflicts of interest claimed to arise if both activities were undertaken within the same unit; the insulation of the banking unit from the risks associated with the securities activities and the elimination of the competitive advantage that an organisation like a universal bank would have in offering securities services because of its access to the safety net (Kwast (1996)). A final reason sometimes presented for keeping securities activities outside the banking unit is that corporate separateness allows for functional regulations, which are claimed to be easier and less expensive to implement than institutional regulations (Herring and Santomero (1990)). ${ }^{42}$

However, some of the benefits claimed to emerge with corporate separateness have been questioned because markets do not perceive the units of a conglomerate to be independent of each other despite their being legally and operationally separated. ${ }^{43}$ The reason is that the conglomerate has an incentive to manage its units as an integrated entity rather than as a portfolio of independent firms in order to exploit the economies of scope. In addition, should one of its units get into financial distress the conglomerate has an incentive to go far beyond its equity investment in the financially

generated by these activities to less than 5 percent of the subsidiary's total revenue to ensure that these subsidiaries were not "principally engaged" in investment banking. In 1989 that revenue limit was increased to 10 percent (recently increased further to 25 percent) and the set of "ineligible" activities was extended to include underwriting and dealing in corporate bonds and equities. See Pollard, Passaic and Daly (1988) for a detailed presentation of the U.S. banking law on state member, nonmember and national banks' securities activities and Carosso (1970), Perkins (1971), White (1986) or Mote and Kaufman (1989) for a history of commercial banks' securities activities.

40 See Santos (1998b) for an extensive discussion of these implications.

41 Empirical research on organisational structures is very limited. Two studies about the period before the passage of GlassSteagall produce conflicting results. Kroszner and Rajan (1997) conclude that underwriting securities in a unit outside the bank was helpful in reducing conflicts of interest. Puri (1996) concludes that underwriting securities in-house did not lead to more conflicts of interest than conducting the securities business in a separate unit.

42 Merton (1995) provides a detailed analysis of the issues at stake in implementing functional and institutional regulations.

43 Limited liability does not generally allow the securities unit's creditors (or, for that matter, the creditors of any other unit) to have any claim on the bank's assets. However, there are exceptions to this rule. For example, if the securities unit misled its creditors into thinking that they were dealing with the bank itself, then under the principle of "estoppel" these creditors may have a valid claim on the bank's assets (Black, Miller and Posner (1978)). 
distressed unit because an appeal to the limited liability clause may be costly. ${ }^{44}$ The conglomerate may want to extend its investment in order to protect the reputation of its management (Wall (1984) and Talley (1985)), the market assessment of its debt, or to shield the other units from any potential contagion effects resulting from the failure of a member unit. ${ }^{45}$ Finally, some of the conglomerate's practices and certain procedures of the supervisory agencies can also influence the market's perception of independence among the units of a conglomerate. For example, emphasis on consolidated financial reporting or procedures whereby the authorities oversee the financial affairs of nonbanking units as well as those of the entire conglomerate will reinforce the integrated entity perception in the marketplace.

Corporate separateness, besides being questioned, is also criticised for introducing a few costs of its own, some of them increasing with the "distance" it imposes between the units of the conglomerate. It requires the development and operation of a more costly organisation because of the cost of developing and operating an additional separately capitalised unit. It limits the conglomerate's ability to exploit the scope economies. It introduces a new series of distortions, such as the agency problems associated with multiple management teams. In addition, separateness may be the source of some conflicts of interest, such as those that can arise when the banking and securities units have different ownership structures. If the banking unit's capital and the securities unit's capital are not owned proportionately by the same shareholders, then there will be opportunities to favour one group of shareholders at the expense of the other (Edwards (1979) and Saunders (1985)).

Some of the advantages and disadvantages of separating the banking unit from the securities unit, such as the potential reduction in conflicts of interest that may arise with that combination of activities and the potential reduction in scope economies, do not seem greatly affected by the organisational structure - the bank-parent model or the holding-company model - adopted (or required) to implement separateness. Other effects, however, do appear to be dependent on that structure because in the bank-parent model there is a direct relationship between the bank and the securities unit while in the holding-company model that relationship is only indirect. In the former

44 See Cornyn, Hanweck, Rhoades and Rose (1986) for a review of studies on the management of BHCs in the United States and FDIC (1987, Chapter 6) for several examples of banking organisations helping financially troubled nonbanking affiliates, some of them involving bank-sponsored real estate investment trusts in the mid-1970s. Conglomerates' incentive to protect their member units is illustrated by the following statement by Walter Wriston, former chairman of Citicorp: "It is inconceivable that any major bank would walk away from any subsidiary of its holding company. If your name is on the door, all of your capital funds are going to be behind it in the real world. Lawyers can say you have separation, but the market place is persuasive, and it would not see it that way." In Financial Institutions Restructuring and Services Act of 1981, Hearings on S. 1686, S. 1703, S. 1720 and S. 1721, before the Senate Committee on Banking, Housing, and Urban Affairs, 97th Congress, 1st Session, Part II, 589--590.

45 The runs on the Beverly Hills National Bank in 1974 are sometimes presented as an example of a contagion run caused by an internal noisy signal. They started when it became public that the bank's parent, the Beverly Hills Bancorp, had incurred significant losses in its real estate investment trust. The crisis ended with the sale of the troubled bank to the Wells Fargo bank. See Cornyn et al. (1986) for other examples of bank failures involving problems with their nonbank affiliates, and Aharony and Swary (1983) and Flannery (1986) for a discussion of the contagion effects caused by the release of information. 
model, the securities unit's capital is an asset of the bank, its profits accrue to the bank, and, if it fails, limited liability confines the bank's losses to the investment made in that unit. In the latter model, because the securities unit's capital is an asset of the holding company, that is, there is a cushion - the holding company - between the bank and the securities unit, all those relationships are with the holding company and not with the bank.

On the basis of these differences, it is usually argued that the holding-company model makes it easier to limit the safety net coverage to the traditional banking activities, provides better insulation to the bank from problems that may emerge in its sister securities unit, and gives the bank less incentive to bail out the securities unit because this is a sister affiliate rather than a directly owned subsidiary (Herring and Santomero (1990)). However, it is also frequently argued that the bank-parent model is less expensive to develop and operate because it does not require an additional company the holding company. It gives the bank more control over its securities unit's profits because these can leave the conglomerate as profits only through the bank, while in the holding-company model they can leave through the holding company. And it gives the bank's creditors a claim over a larger pool of assets because in that model the securities unit's capital is an asset of the bank while in the holdingcompany model it is an asset of the holding company, and hence beyond the reach of the bank's creditors. As a result, if a bank gets into financial trouble, its creditors can claim the investment in the securities unit if the conglomerate is organised on the bank-parent model, but they cannot do so if the conglomerate is organised on the holding-company model. ${ }^{46}$

In conclusion, the debate on corporate separateness remains unsettled. The effectiveness of corporate separateness continues to be questioned on several grounds and neither of the two models most frequently adopted to implement separateness - the holding-company model and the bank-parent model - has proven itself superior to the other. It remains a fact, though, that in countries where banks have more latitude to choose their corporate structure to integrate securities activities with commercial banking activities, they generally choose either to undertake these activities in-house (as in Germany, Italy, the Netherlands and Switzerland) or to conduct them in a subsidiary of the bank (as in the United Kingdom). The holding-company model predominates only in the United States, but this appears to be the result of regulation. It should be taken into account, however, that a certain conglomerate model may predominate not because it is the most efficient way to integrate the activities but because of factors idiosyncratic to the country or because market imperfections make it the best organisational structure to extract rents. ${ }^{47}$

46 Regulators in the United States have attempted to introduce this effect in the holding-company model, through the socalled "source of strength" doctrine, according to which the holding company has the duty to act as a source of financial and managerial strength to its banking subsidiary. It remains unclear, however, whether this doctrine can be legally enforced.

47 See Cumming and Sweet (1987), Koguchi (1993) and Barth, Nolle and Rice (1997) for the permissible and the predominant corporate structures in several countries. 


\section{Final remarks}

In a competitive environment where financial intermediaries such as commercial banks exist because of the liquidity and monitoring services they perform, setting aside the distortions created by the mechanisms that protect them from runs on their deposits, it seems difficult to argue that these institutions should be barred from the securities business.

In that environment, it appears that potentially important gains in efficiency could result from combining traditional commercial banking with securities activities. These gains would come from the enhancement of the bank-firm relationship and the economies of scope in the production and consumption of financial services. There are usually two concerns in regard to the banking-securities combination - the safety and soundness of banks and the conflicts of interest. As in the loans business, there is risk in the securities business, but as in the case of loans, the risk associated with securities activities is manageable. Therefore, allowing banks to enter the securities business would give them an additional opportunity to diversify, that is, an opportunity to create an alternative source of revenue for periods of disintermediation (when firms sidestep commercial banks and obtain funding directly from capital markets using the services provided by investment banks). Regarding the conflicts-of-interest concern, institutions' incentives and opportunities to exploit these conflicts are constrained by the importance they attribute to their reputations and by investors' expected rational behaviour, respectively. Thus, provided that markets remain competitive and the contracting parties disclose the information deemed necessary in a timely fashion, conflicts of interest do not seem to constitute a solid reason for prohibiting commercial banks from undertaking securities activities.

With respect to the location of the securities unit within the organisational structure of a banking organisation, in a competitive market without the safety net distortions the bank would choose the most appropriate corporate structure by trading off the advantages of undertaking securities activities in-house (namely, the economies of scope) with the costs of doing so (namely, the premium the market may impose on some of the bank's services because of potential conflicts of interest). Because these effects vary with the securities activities, some banks would attempt to minimise the potential for such conflicts by separating some of their in-house activities with firewalls. Others would choose instead to conduct more sensitive securities businesses in a subsidiary of the bank, and others still would go even further by creating a holding company and carrying out securities activities in a sister affiliate of the bank. Under these circumstances, there does not appear to be any fundamental justification for prohibiting banks from undertaking securities activities or for limiting their choice of corporate structure.

The question thus becomes one of whether the moral hazard introduced by the safety net justifies a regulation prohibiting banks from entering the securities business, and if not, whether it justifies a regulation requiring banks to adopt a particular organisational form. These questions have been at the centre of the debate over the repeal of Glass-Steagall. The research and the evidence, 
historical and international, reviewed here make a compelling case for answering both questions with a qualified no.

Considering the potential gains from combining traditional commercial banking with securities activities, it would seem desirable to allow commercial banks to enter the securities business and to give them some latitude in choosing their corporate structure. The problem of the risk-shifting incentives created by deposit insurance should be addressed by adopting mechanisms that curtail these incentives and abolishing policies that augment them (for example, introducing a credible bank closure rule, eliminating the "too-big-to-fail" possibility, and introducing a greater sensitivity of the insurance premium to the bank's risk). ${ }^{48}$ That problem should not be addressed through the introduction of prohibitions, such as that against entering the securities business, which affect all banks alike, regardless of pertinent factors, such as banks' capitalisation, that determine their risk-shifting incentives. Moreover, that problem should not be used as the main reason for implementing regulations that require a particular organisational structure. History has shown the many limitations of corporate separateness and has demonstrated how fragile firewalls can be, particularly when they are most needed, that is, in situations of financial distress. A policy that allows banks to choose their corporate structure, possibly making the choice dependent on their capitalisation, appears far more appropriate, because it would give them the opportunity to explore the advantages of various organisational structures.

48 See Kane (1986) and Schwartz (1992) for measures that could be adopted to reduce the risk-shifting incentives introduced by the safety net. 


\section{References}

Aharony, J. and I. Swary (1983): "Contagion Effects of Bank Failures: Evidence from Capital Markets". Journal of Business 56, pp. 213-30.

Allen, F. and G. Gale (1997): "Financial Markets, Intermediaries, and Intertemporal Smoothing". Journal of Political Economy 105, pp. 523-46.

Allen, F. and A. Winton (1995): "Corporate Financial Structure, Incentives and Optimal Contracting". Handbooks in Operations Research and Management Science, Vol. 9, Finance, R. A. Jarrow, V. Maksimovic and W. T. Ziemba, (eds.), New York, North-Holland, pp. 693-720.

Allen, L., A. Saunders and G. F. Udell (1991): "The Pricing of Retail Deposits: Concentration and Information". Journal of Financial Intermediation 1, pp. 335-61.

Ang, J. S. and T. Richardson (1994): "The Underpricing Experience of Commercial Bank Affiliates prior to the Glass-Steagall Act: A Re-examination of Evidence for Passage of the Act". Journal of Banking and Finance 18, pp. 351-95.

Barth, J. R., D. E. Nolle and T. N. Rice (1997): "Commercial Banking Structure, Regulation, and Performance: An International Comparison". Comptroller of the Currency, Working Paper No. 7.

Baumol. W. J., J. C. Panzar and R. D. Willig (1981): Contestable Markets and the Theory of Industrial Structure, New York, Harcourt Brace.

Beatty, R. P. and J. R. Ritter (1986): "Investment Banking, and the Underpricing of Initial Public Offerings". Journal of Financial Economics 15, pp. 213-32.

Benston, G. J. (1990): The Separation of Commercial and Investment Banking: The Glass-Steagall Act Revisited and Reconsidered, New York, Oxford University Press.

Berger, A. N., D. B. Humphrey and L. B. Pulley (1996): "Do Consumers Pay for One-Stop Banking? Evidence from an Alternative Revenue Function". Journal of Banking and Finance 20, pp. 1601-21.

Berger, A. N., W. C. Hunter and S. G. Timme (1993): The Efficiency of Financial Institutions: A Review and Preview of Research Past, Present, and Future". Journal of Banking and Finance 17, pp. 221-49.

Berger, A. N. and G. F. Udell (1995): "Relationship Lending and Lines of Credit in Small Firm Finance". Journal of Business 68, pp. 351-81.

Best, R. and H. Zhang (1993) "Alternative Information Sources and the Information Content of Bank Loans:". Journal of Finance 48, pp. 1507-23.

Bhattacharya, S. and A. V. Thakor (1993): "Contemporary Banking Theory". Journal of Financial Intermediation 3, pp. 2-50.

Billet, M. T., M. J. Flannery and J. A. Garfinkel (1995): "The Effect of Lender Identity on a Borrowing Firm's Equity Return”. Journal of Finance 50, pp. 699-718.

Black, F., M. H. Miller and R. A. Posner (1978): "An Approach to the Regulation of Bank Holding Companies". Journal of Business 51, pp. 379-412. 
Boot, A. W. A. and A. V. Thakor (1997): "Financial System Architecture". Review of Financial Studies 10, pp. 693-733.

Boot, A. W. A. and A. V. Thakor (1996): "Banking Structure and Financial Innovation". Universal Banking: Financial System Design Reconsidered, I. Walter and A. Saunders (eds.), Chicago, Irwin, pp. 420-30.

Boot, A. W. A. and A. V. Thakor (1994): "Moral Hazard and Secured Lending in an Infinitely Repeated Credit Market Game”. International Economic Review 35, pp. 899-920.

Boyd, J. H. and S. L. Graham (1988): "The Profitability and Risk Effects of Allowing Bank Holding Companies to Merge with other Financial Firms: A Simulation Study". Federal Reserve Bank of Minneapolis Quarterly Review 10, pp. 3-20.

Boyd, J. H., S. L. Graham and R. S. Hewitt (1993): "Bank Holding Company Mergers with Nonbank Financial Firms: Effects on the Risk of Failure". Journal of Banking and Finance 17, pp. 43-63.

Boyd, J. H., G. A. Hanweck and P. Pithyachariyakul (1980): "Bank Holding Company Diversification". Proceedings of a Conference on Bank Structure and Competition, Federal Reserve Bank of Chicago, pp. 105-21.

Brewer, E. III, D. Fortier and C. Pavel (1989): "Bank Risk from Nonbank Activities". Journal of International Securities Markets 3, pp. 199-210.

Bröker, G. (1989): Competition in Banking, Paris, OECD.

Bryan, L. L. (1988): Breaking up the Bank: Rethinking an Industry under Siege, Homewood, Illinois, Dow Jones-Irwin.

Bryant, J. (1980): “A Model of Reserves, Bank Runs, and Deposit Insurance”. Journal of Banking and Finance 4, pp. 335-44.

Calomiris, C. W. (1995): "The Costs of Rejecting Universal Banking: American Finance in the German Mirror, 1870-1914". Coordination and Information, N. Lamoreaux and D. Raff (eds.), Chicago, University of Chicago Press, pp. 257-321.

Calomiris, C. W. (1992): "Remarks on Inside Information in Banking". in Proceedings to a Conference on Bank Structure and Competition, Federal Reserve Bank of Chicago, pp. 293-301.

Calomiris, C. W. and G. Gorton (1991): "The Origins of Banking Panics". Financial Markets and Financial Crisis, G. Hubbard (ed.), Chicago, University of Chicago Press, pp. 109-72.

Calomiris, C. W. and C. M. Kahn (1991): "The Role of Demandable Debt in Structuring Optimal Banking Arrangements”. American Economic Review 81, pp. 497-513.

Carosso, V. P. (1970): Investment Banking in America: A History, Cambridge, Mass., Harvard University Press.

Carter, R. and S. Manaster (1990): "Initial Public Offerings and Underwriter Reputation". Journal of Finance 45, pp. 1045-67.

Chari, V. V. and R. Jagannathan (1988): "Banking Panics, Information, and Rational Expectations Equilibrium". Journal of Finance 43, pp. 749-61. 
Chemmanur, T. J. and P. Fulghieri (1994): "Reputation, Renegotiation, and the Choice between Bank Loans and Publicly Traded Debt". Review of Financial Studies 7, pp. 475-506.

Clark, J. A. (1988): "Economies of Scale and Scope at Depository Financial Institutions: A Review of the Literature". Economic Review, Federal Reserve of Kansas City, September/October, pp. 16-33.

Cornyn, A, G. Hanweck, S. Rhoades and J. Rose (1986): “An Analysis of the Concept of Corporate Separateness in BHC Regulation from an Economic Perspective". Proceedings of a Conference on Bank Structure and Competition, Federal Reserve Bank of Chicago, pp. 174-212.

Cumming, C. M. and L. M. Sweet (1987): "Financial Structure of the G-10 Countries: How does the United States Compare?" Federal Reserve Bank of New York, Quarterly Review, Winter, pp. 14-25.

Dewatripont, M. and J. Tirole (1994): The Prudential Regulation of Banks, Cambridge, Massachusetts, The MIT Press.

Diamond, D. W. (1991) "Monitoring and Reputation: The Choice between Bank Loans and Directly Placed Debt". Journal of Political Economy 99, pp. 689-721.

Diamond, D. W. (1984): "Financial Intermediation and Delegated Monitoring". Review of Financial Studies 51, pp. 393-414.

Diamond, D. W. and P. H. Dybvig (1986): "Banking Theory, Deposit Insurance, and Bank Regulation". Journal of Business 59, pp. 53-68.

Diamond, D. W. and P. H. Dybvig (1983): "Bank Runs, Deposit Insurance and Liquidity". Journal of Political Economy 91, pp. 401-19.

Dothan, U. and J. Williams, (1980): "Banks, Bankruptcy, and Public Regulation”. Journal of Banking and Finance 4, pp. 65-88.

Edwards, F. R. (1979): "Banks and Securities Activities: Legal and Economic Perspectives on the Glass-Steagall Act". The Deregulation of Banking and Securities Activities, L. G. Goldberg and L. J. White (eds.), Lexington, Mass., Lexington Books, pp. 273-94.

Edwards, G. W. (1942): "The Myth of the Security Affiliate". Journal of the American Statistical Association 37, pp. 225-32.

Eisenbeis, R. A. (1996): "Banks and Insurance Activities". Universal Banking: Financial System Design Reconsidered, I. Walter and A. Saunders (eds.), Chicago, Irwin, pp. 387-412.

FDIC (1987): Mandate for Change: Restructuring the Banking Industry, Washington DC.

Flannery, M. J. (1986): "Contagious Bank Runs, Financial Structure and Corporate Separateness within a Bank Holding Company". Proceedings of a Conference on Bank Structure and Competition, Federal Reserve Bank of Chicago, pp. 213-30.

Forestieri, G. (1993): "Economies of Scale and Scope in the Financial Services Industry: A Review of Recent Literature". Financial Conglomerates, Paris, OECD, pp. 63-124.

Freixas, X. and J. C. Rochet (1997): Microeconomics of Banking, Cambridge, Mass., MIT Press. 
Gande, A., M. Puri, A. Saunders and I. Walter (1997): "Bank Underwriting of Debt Securities: Modern Evidence”. Review of Financial Studies 10, pp. 1175-202.

GAO (1995): "Banks' Securities Activities: Oversight Differs Depending on Activity and Regulator". General Accounting Office Report No. 214.

Gorton, G. (1988): “Banking Panics and Business Cycles”. Oxford Economic Papers 40, pp. 751-81.

Gorton, G. and J. G. Haubrich (1987): "Bank Deregulation, Credit Markets, and the Control of Capital”. Carnegie-Rochester Conference Series on Public Policy 26, pp. 289-334.

Gorton, G. and G. Pennacchi (1992): "Money Market Funds and Finance companies: Are they the Banks of the Future?" Structural Change in Banking, M. Klausner and L. White (eds.), Homewood, Illinois, Irwin, pp. 173-214.

Gorton, G. and G. Pennacchi (1990): "Financial Intermediaries and Liquidity Creation". Journal of Finance 45, pp. 49-71.

Greenbaum, S., G. Kanatas and I. Venezia (1989): "Equilibrium Loan Pricing under the Bank Client Relationship". Journal of Banking and Finance 13, pp. 221-35.

Hand, J. R. M., R. W. Holthausen and R. W. Leftwich (1992): “The Effect of Bond Rating Agency Announcements on Bond and Stock Prices". Journal of Finance 47, pp. 733-52.

Harris, M. and A. Raviv (1991): "The Theory of Capital Structure". Journal of Finance 46, pp. 297-355.

Herring, R. J. and A. M. Santomero (1990): "The Corporate Structure of Financial Conglomerates". Journal of Financial Services Research 4, pp. 471-97.

Holthausen, R. W. and R. W. Leftwich (1986): "The Effect of Bond Rating Changes on Common Stock Prices". Journal of Financial Economics 17, pp. 57-89.

Holthausen, R. W., R. W. Leftwich and D. Mayers (1987): "The Impact of Large Block Transactions on Securities Prices: A Cross-Section Analysis". Journal of Financial Economics 19, pp. 237-67.

Hubbard, R. G. (1997): "Capital Market Imperfections and Investment". National Bureau of Economic Research Working Paper No. 5996.

Jacklin, C. (1987): "Demand Deposits, Trading Restrictions, and Risk-Sharing". Contractual Arrangements for Intertemporal Trade, E. C. Prescott and N. Wallace (eds.), University of Minnesota Press, pp. 26-47.

Jacklin, C. and S. Bhattacharya (1988): "Distinguishing Panics and Information-Based Bank Runs: Welfare and Policy Implications". Journal of Political Economy 96, pp. 568-92.

James, C. (1987): "Some Evidence on the Uniqueness of Bank Loans". Journal of Financial Economics 19, pp. 217-35.

Kanatas, G. and J. Qi (1995): Underwriting by Commercial Banks: Conflicts of Interest vs. Scope Economies, Mimeo. College of Business Administration, University of South Florida.

Kane, E. J. (1996): "The Increasing Futility of Restricting Bank Participation in Insurance Activities". Universal Banking: Financial System Design Reconsidered, I. Walter and A. Saunders (eds.), Chicago, Irwin, pp. 338-417. 
Kane, E. J. (1986): "Confronting Incentive Problems in US Deposit Insurance: The Range of Alternative Solutions". Deregulating Financial Services, G. G. Kaufman and R. C. Kormendi (eds.), Cambridge, Mass., Ballinger Publishing Company, pp. 97-120.

Kareken, J. H. (1986): "Federal Bank Regulatory Policy: A Description and Some Observations". Journal of Business 59, pp. 3-48.

Kareken, J. H. and N. Wallace (1978): "Deposit Insurance and Bank Regulation: A PartialEquilibrium Exposition". Journal of Business 51, pp. 413-38.

Kelly, E. J. (1985a): "Legislative History of the Glass-Steagall Act". Deregulating Wall Street: Commercial Bank Penetration of the Corporate Securities Market, I. Walter (ed.), New York, John Wiley \& Sons, pp. 41-66.

Kelly, E. J. (1985): "Conflicts of Interest: A Legal View". Deregulating Wall Street: Commercial Bank Penetration of the Corporate Securities Market, I. Walter, New York, John Wiley \& Sons, pp. 231-54.

Koguchi, K. (1993): "Financial Conglomeration”. Financial Conglomerates, Paris, OECD, pp. 7-62.

Kroszner, R. S. and R. G. Rajan (1997): "Organisation Structure and Credibility: Evidence from Commercial Bank Securities Activities before the Glass-Steagall Act". Journal of Monetary Economics 39, pp. 474-516.

Kroszner, R. S. and R. G. Rajan (1994): "Is the Glass-Steagall Act Justified? A Study of the U.S. Experience with Universal Banking before 1933". American Economic Review 84, pp. 810-832.

Krümmel, H. J. (1980): "German Universal Banking Scrutinised: Some Remarks concerning the Gessler Report". Journal of Banking and Finance 4, pp. 33-55.

Kwast, M. L. (1996): "Supervising the Universal Bank". Universal Banking: Financial System Design Reconsidered, I. Walter and A. Saunders (eds.), Chicago, Irwin, pp. 743-49.

Kwast, M. L. (1989): “The Impact of Underwriting and Dealing on Bank Returns and Risks”. Journal of Banking and Finance 13, pp. 102-25.

Litan, R. E. (1987): What Should Banks Do? The Brookings Institution, Washington, D.C.

Litan, R. E. (1985): "Evaluating and Controlling the Risks of Financial Product Deregulation". Yale Journal on Regulation 3, pp. 1-52.

Llewellyn, D. T. (1996): "Universal Banking and the Public Interest: A British Perspective". Universal Banking: Financial System Design Reconsidered, I. Walter and A. Saunders (eds.), Chicago, Irwin, pp. 161-204.

Loderer, C. F., D. P. Sheehan and G. B. Kadlec (1991): "The Pricing of Equity Offerings". Journal of Financial Economics 29, pp. 35-57.

Lummer, S. and J. J. McConnell (1989): "Further Evidence on the Bank Lending Process and the Capital Market Response to Bank Loan Agreements". Journal of Financial Services Research 25, pp. 99-112.

Merton, R. C. (1995): “A Functional Perspective of Financial Intermediation”. Financial Management 24 , pp. 23-41. 
Merton, R. C. (1978): "On the Costs of Deposit Insurance When There are Surveillance Costs". Journal of Business 51, pp. 439-52.

Merton, R. C. (1977): "An Analytic Derivation of the Cost of Deposit Insurance Loan Guarantees". Journal of Banking and Finance 1, pp. 3-11.

Mikkelson, W. and M. Partch (1986): "Valuation Effects of Security Offerings and the Issuance Process". Journal of Financial Economics 15, pp. 31-60.

Moore, T. (1934): "Security Affiliate versus Private Investment Banker - A Study in Security Organisations". Harvard Business Review 12, pp. 478-84.

Mote, L. R. and G. G. Kaufman (1989): "Securities Activities of Commercial Banks: The Current Economic and Legal Environment". Research in Financial Services 1, pp. 223-62.

Mudur, U. (1992): "Economies of Scale and Scope. in National and Global Banking Markets". The New European Financial Marketplace, A. Steinherr (ed.), New York, New York University Press, pp. 31-48.

Myers, S. C. (1984): “The Capital Structure Puzzle”. Journal of Finance 39, pp. 575-92.

Nakamura, L. I. (1993): "Commercial Bank Information: Implications for the Structure of Banking". Structural Change in Banking, M. Klausner and L. J. White (eds.), Illinois, Business One Irwin, pp. 131-60.

OECD (1992): Insurance and Other Financial Services: Structural Trends, Paris.

Peach, W. N. (1941): The Security Affiliates of National Banks, Baltimore, Johns Hopkins University Press.

Perkins, E. J. (1971): “The Divorce of Commercial and Investment Banking”. Banking Law Journal 88 , pp. 483-528.

Petersen, M. and R. Rajan (1994): "The Benefits of Lending Relationships: Evidence from Small Business Data". Journal of Finance 49, pp. 3-37.

Pierce, J. L. (1991): The Future of Banking, New Haven, Connecticut, Yale University Press.

Pollard, A. M., J. G. Passaic, K. H. Ellis, and J. P. Daly (1988): Banking Law in the United States, Boston, Butterworth Legal Publishers.

Pulley, L. B. and D. B. Humphrey (1993): "The Role of Fixed Costs and Cost Complementarities in Determining Scope Economies and the Cost of Narrow Banking Proposals". Journal of Business 66, pp. 437-62.

Puri, M. (1996): "Commercial Banks in Investment Banking: Conflict of Interest or Certification Role?” Journal of Financial Economics 40, pp. 373-401.

Puri, M. (1995): "Conflicts of Interest, Intermediation, and the Pricing of Underwritten Securities". Mimeo, Graduate School of Business, Stanford University.

Puri, M. (1994): "The Long-Term Default Performance of Bank Underwritten Security Issues". Journal of Banking and Finance 18, pp. 397-418. 
Rajan, R. G. (1996): "The Entry of Commercial Banks into the Securities Business: A Selective Survey of Theories and Evidence". Universal Banking: Financial System Design Reconsidered, I. Walter and A. Saunders (eds.), Chicago, Irwin, pp. 282-302.

Rajan, R. G. (1994): "An Investigation into the Economics of Extending Bank Powers". Mimeo, Graduate School of Business, University of Chicago.

Rajan, R. G. (1992): “Insiders and Outsiders: The Choice between Informed and Arm's-Length Debt”. Journal of Finance 48, pp. 1367-1400.

Ramakrishnan, R. and A. Thakor (1984): "Information Reliability and the Theory of Financial Intermediation”. Review of Economic Studies 51, pp. 415-52.

Santomero, A. M. and E. J. Chung (1992): "Evidence in Support of Broader Bank Powers". Financial Markets, Institutions \& Instruments 1, New York University, Salomon Center, pp. 1-69.

Santos, J. A. C. (1998a): "Mixing Banking with Commerce: A Review". Mimeo, Bank for International Settlements.

Santos, J. A. C. (1998b): "Securities Units of Banking Conglomerates: Should their Location be Regulated?" Forthcoming in the Cato Journal.

Saunders, A. (1994): "Banking and Commerce: An Overview of the Public Policy Issues". Journal of Banking and Finance 18, pp. 231-54.

Saunders, A. (1985a): "Conflicts of Interest: An Economic View". Deregulating Wall Street: Commercial Bank Penetration of the Corporate Securities Market, I. Walter (ed.), John Wiley \& Sons, New York, pp. 207-30.

Saunders, A. (1985b): "Bank Safety and Soundness and the Risks of Corporate Securities Activities". Deregulating Wall Street: Commercial Bank Penetration of the Corporate Securities Market, I. Walter (ed.), John Wiley \& Sons, New York, pp. 171-206.

Saunders, A. and I. Walter (1994): Universal Banking in the United States: What Could we Gain? What Could we Loose? New York, Oxford University Press.

Schwartz, A. J. (1992): “The Misuse of the Fed's Discount Window". Federal Reserve Bank of St. Louis, Economic Review, September/October, pp. 58-69.

Shaffer, S. (1984): "Cross-Subsidisation in Checking Accounts". Journal of Money Credit and Banking 16, pp. 100-9.

Sharpe, S. (1990): “Asymmetric Information, Bank Lending and Implicit Contracts: A Stylised Model of Customer Relationships". Journal of Finance 45, pp. 1069-87.

Slovin, M. B., S. A. Johnson and J. L. Glascock (1992): "Firm Size and the Information Content of Bank Loan Announcements". Journal of Banking and Finance 16, pp. 1057-71.

Slovin, M. B., M. E. Sushka and C. D. Hudson (1990): "External Monitoring and its Effect on Seasoned Common Stock Issues". Journal of Accounting and Economics 12, pp. 397-417.

Smith, C. W. (1986): "Investment Banking and the Capital Acquisition Process". Journal of Financial Economics 15, pp. 3-29. 
Steinherr, A. and C. Huveneers (1990): "Universal Banks: The Prototype of Successful Banks in the Integrated European Market? A View Inspired by the German Experience". Center for European Policy Studies, Financial Markets Unit, Working Paper No. 2.

Stickel, S. (1986): "The Effect of Preferred Stock Rating Changes on Preferred and Common Stock Prices". Journal of Accounting and Economics 8, pp. 197-216.

Talley, S. H. (1985): “Activity Deregulation and Banking Stability”. Issues in Bank Regulation 9, pp. 32-8.

Udell, G. F. (1986): "Pricing Return Check Charges under Asymmetric Information". Journal of Money, Credit and Banking 18, pp. 496-505.

Wall, L. D. (1984): "Insulating Banks from Nonbank Affiliates". Federal Reserve Bank of Atlanta, Economic Review 69, pp. 18-28.

Wall, L. D. and R. A. Eisenbeis (1984): "Risk Considerations in Deregulating Bank Activities". Federal Reserve Bank of Atlanta, Economic Review, May, pp. 6-19.

Wallace, N. (1996): "Narrow Banking Meets the Diamond-Dybvig Model”. Federal Reserve Bank of Minneapolis, Quarterly Review, Winter, pp. 3-13.

White, E. N. (1986): "Before the Glass-Steagall Act: An Analysis of the Investment Banking Activities of National Banks". Explorations in Economic History 23, pp. 33-55.

Yosha, O. (1995): “Information Disclosure Costs and the Choice of Financing Structure" . Journal of Financial Intermediation 4, pp. 3-20. 



\section{Recent BIS Working Papers}

No.

39

January 1997

40

March 1997

41

May 1997

42

June 1997

43

July 1997

44

July 1997

45

August 1997

46

September 1997

47

September 1997

48

September 1997

49

September 1997

50

November 1997

51

November 1997

52

January 1998

53

March 1998

54

June 1998

55

June 1998
Title

Author

Banking system failures in developing and transition countries: diagnosis and prediction

Monetary policy operating procedures in industrial countries

The euro and European financial markets

Measuring monetary policy shocks in France, Germany and Italy: the role of the exchange rate

Exchange rate regimes and the expectations hypothesis of the term structure

Is there excess comovement of bond yields between countries?

A multi-country comparison of the linkages between inflation and exchange rate competitiveness

Global asset allocation in fixed income markets

Financial asset prices and monetary policy: theory and evidence

Some multi-country evidence on the effects of real exchange rates on output

Why does the yield curve predict economic activity? Dissecting the evidence for Germany and the United States

The euro and the dollar

Forecast errors and financial developments

Inflation and disinflation in Iceland

Exchange rate regimes and inflation and output in SubSaharan countries

The coming transformation of continental European banking?

Spread overreaction in international bond markets
Patrick Honohan

Claudio E. V. Borio

Robert N. McCauley and William R. White

Frank Smets

Stefan Gerlach and Frank Smets

Gregory D. Sutton

Steven B. Kamin

Srichander

Ramaswamy

Frank Smets

Steven B. Kamin and Marc Klau

Frank Smets and Kostas Tsatsaronis

Robert N. McCauley

Palle S. Andersen

Palle S. Andersen and Már Guðmundsson

Marc Klau

William R. White

Gregory D. Sutton 